\title{
OPTIMASI DESAIN STRUKTUR BED MESIN BUBUT CNC TERHADAP PENGARUH DEFLEKSI, FREKUENSI PRIBADI DAN PROSES MANUFAKTUR MILLING
}

\author{
Ardhi Priantoko \\ Fakultas Teknik, Program Studi Teknik Mesin \\ Universitas Muria Kudus \\ Email: ardhi180@yahoo.com \\ Achmad murdifin \\ Fakultas Teknik, Program Studi Teknik Mesin \\ Universitas Muria Kudus \\ Email: achmad.murdifin@yahoo.com \\ Afin Adkhiyan \\ Fakultas Teknik, Program Studi Teknik Mesin \\ Universitas Muria Kudus \\ Email: afinadkhiyan@gmail.com \\ Sugeng Slamet \\ Fakultas Teknik, Program Studi Teknik Mesin \\ Universitas Muria Kudus \\ Email: sugeng_hanun@yahoo.co.id
}

\begin{abstract}
ABSTRAK
Tujuan utama dari optimasi desain ini adalah untuk meningkatkan kualitas dari mesin bubut yang akan dibuat BMEPPO-BBPT. Dengan tetap menggunakan material Gray cast iron (FC25) serta menekan jumlah material yang di butuhkan dalam pembuatan bed bubut tersebut tetapi menghasilkan bentuk desain Slant Bed bubut CNC yang optimal sehingga tidak mengurangi kualitas mesin yang akan dibuat. Perancangan struktur bed menggunakan ribbing dapat membuat mesin tetap kokoh dan mampu mengatasi pembebanan yang terjadi akibat berat komponen mesin bubut, namun tetap memenuhi aspek berat yang tidak berlebihan. Proses perancangan dilakukan melalui metode reverse engineering dari desain mesin bubut CNC Leadwell T-6, yang berikutnya akan dimodifikasi untuk melihat perilaku statis tepatnya pada defleksi, perilaku dinamis serta frekuensi dari desain yang akan diuji menggunakan pendekatan software analisis. Hasil akhirnya adalah mendapatkan desain dengan defleksi terkecil serta gambar desain manufaktur untuk membantu proses permesinan milling pada tahap bembuatan bed mesin bubut CNC tersebut.
\end{abstract}

Kata kunci: Bed, defleksi, frekuensi, dan desain manufaktur.

\begin{abstract}
The mainly purpose from this design optimization to increase lathe quality which will made by BMEPPO-BPPT. Decided use Gray cast iron (FC25) as material and losing weight on production but can create optimal CNC lathe slant bed design and will not decreasing machine quality. Design structure of bed use ribbing methode can save machine stiffness and hold all load from lathe machine component but still can kept that weight not excessive. Design procces use Reverse Engineering methode from CNC Leadwell T-6 machine and then will modified to see the dynamic and static characteristic. Result of this optimization is give design with low deflection and manufacturing design for help milling procces.
\end{abstract}

Keywords: Bed, deflection, frequency and manufacturing design.

\section{PENDAHULUAN}

Mesin perkakas adalah salah satu pendukung dari berkembangnya industri manufaktur di seluruh dunia. Dilihat dari negara-negara maju seperti Jepang, Jerman dan Amerika serikat dengan perkembangan industrinya mereka menjadi pemasok utama di dunia. Di indonesia sendiri perkembangan sektor industri mesin perkakas masih jauh tertinggal.

Balai Mesin Perkakas, Teknik Produksi, dan Otomasi - BPPT (disingkat BMEPPO - BPPT) berencana membuat mesin bubut CNC yang akan di-reverse desainnya dari mesin bubut Leadwell T-6 buatan Taiwan. 
Dipilihnya mesin Leadwell T-6 ini karena dari target harga dan kualitas mesin yang masih terjangkau dan berdasarkan survey harga per komponen mesin, harga akhir yang diharapkan bisa lebih murah dari mesin yang sudah ada, sehingga mesin produksi BPPT mampu bersaing dengan mesin buatan China ataupun Taiwan dalam perkembangannya.

Beberapa penelitian dilakukan untuk meningkatkan kualitas mesin bubut terutama pada bagian bed yang menjadi baian terpenting dalam struktur mesin perkakas. Salah satu metode yang digunakan adalah penambahan ribbing atau penyangga pada struktur bed. Metode ini dinilai paling efisien pada aspek penggunaan material karena dengan jumlah material yang rendah tetapi dapat meningkatkan kekuatan struktur [1].

Nilai kekuatan desain bed dapat diketahui melaui analisa pengujian menggunakan pendekatan software analisis CAD. Pendekatan ini dipilih karena tidak memunggkinkan untuk pembuatan prototipe asli dari bed yang akan dibuat sebagai pengujian secara langsung karena membutuhkan biaya yang mahal dalam pembuatannya.

Tulisan ini akan menyajikan proses optimasi desain bed pada tahap modifikasi desain, analisa desain terhadap kekuatan statis mendapatkan besar defleksi struktur, serta desain manufaktur berupa gambar permesinan untuk proses pengerjaan permukaan dengan menggunakan mesin milling pada tahap selanjutnya.

\section{STUDI PUSTAKA}

Mesin perkakas terdiri dari struktur mesin, Bed, kolom, Housing. Bed adalah dasar dari mesin perkakas di mana guideways, spindle, dan komponen lain dipasang. Struktur mesin tersebut harus mampu menahan beban maksimal dari komponen dan benda kerja. Mesin perkekas memiliki karakter keakuratan produksi yang lebih tinggi dibandingkan dengan mesin pembentukan logam. Mesin perkakas digunakan untuk proses produksi barang dalam jumlah yang relatif kecil atau sedikit. Sebaliknya dengan mesin pembentukan logam secara ekonomis untuk memproduksi barang dalam jumlah banyak [2].

Sebuah mesin perkakas harus mampu menjaga stabilitas kerja dan harus memenuhi beberapa kriteria umum seperti : kekakuan statis yang tinggi; menghindari frekuensi pribadi yang tidak dapat diterima agar tidak terjadi resonansi; menahan getaran pada level yang dapat diterima; kapasitas redaman yang memadai (damping); kecepatan dan pemakanan tinggi; tingkat keausan yang rendah di bagian Sliding Part; distorsi termal yang rendah dari komponen mesin perkakas yang berbeda; desain, pengembangan, pemeliharaan, perbaikan, dan biaya produksi rendah [2].

Seperti yang ditunjukkan pada gambar 1 struktur mesin perkakas dapat dibagi menjadi 2 yaitu Open Frames / Struktur Terbuka. Struktur terbuka memiliki kemudahan untuk mengakses pahat/alat potong dan benda kerja. Struktur bertipe terbuka dapat kita jumpai di mesin bubut, bor, sekrap, dan freis. Pada mesin bubut struktur ini disebut bed, sedangkan pada mesin freis dan gurdi, struktur ini disebut kolom. Closed Frames / Struktur tertutup. Struktur tertutup memiliki kekakuan yang amat baik namun akses untuk benda kerja dan pahat cenderung sulit. Struktur tertutup dapat dijumpai di mesin press dan mesin uji tarik.
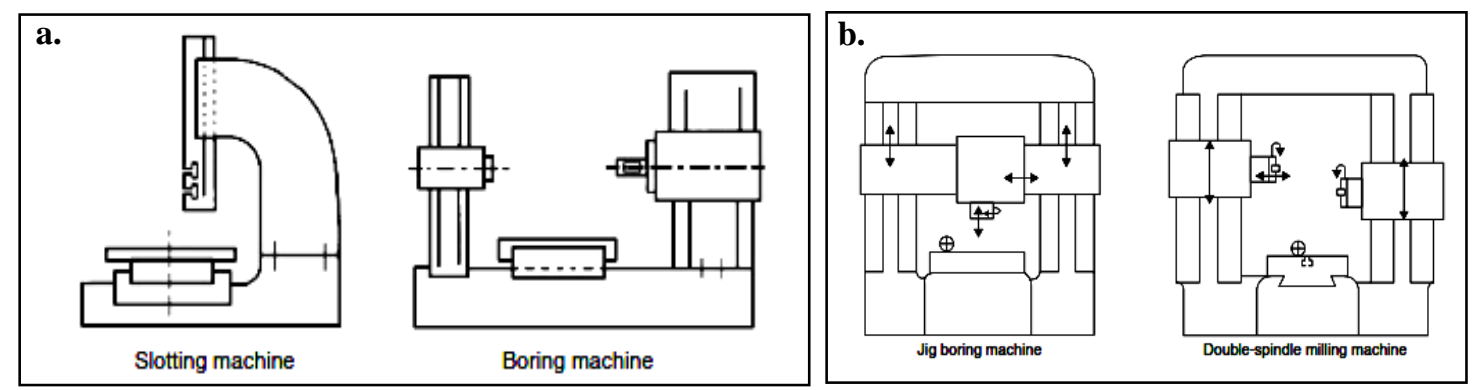

Gambar 1. a. Struktur Mesin terbuka; b. Struktur Mesin Tertutup [2]

Perancangan struktur mesin perkakas disesuaikan dengan kebutuhan gerak pemotongan dan pemakanan, panjang langkah, serta ukuran dan kapasitas mesin. Dalam hal ini, pembuangan Chip, travel, pemasangan, dan pemeliharaan juga dipertimbangkan. Tingkat pemindahan bahan menentukan kapasitas daya alat mesin dan karenanya besarnya gaya potong. Kelas akurasi produksi dipengaruhi oleh deformasi dan lendutan struktur, yang harus dijaga dalam batas yang ditentukan. Penilaian perilaku struktur alat mesin diperoleh dengan mengevaluasi karakteristik statis dan dinamis [3].

Secara umum pada gambar 2, di dalam mesin bubut CNC ada 5 komponen utama, yaitu bed, tooling system/turret, guideways, tailstock, dan headstock. Untuk komponen mesin seperti pahat, scrap conveyor dapat dimasukkan kategori komponen tambahan. 


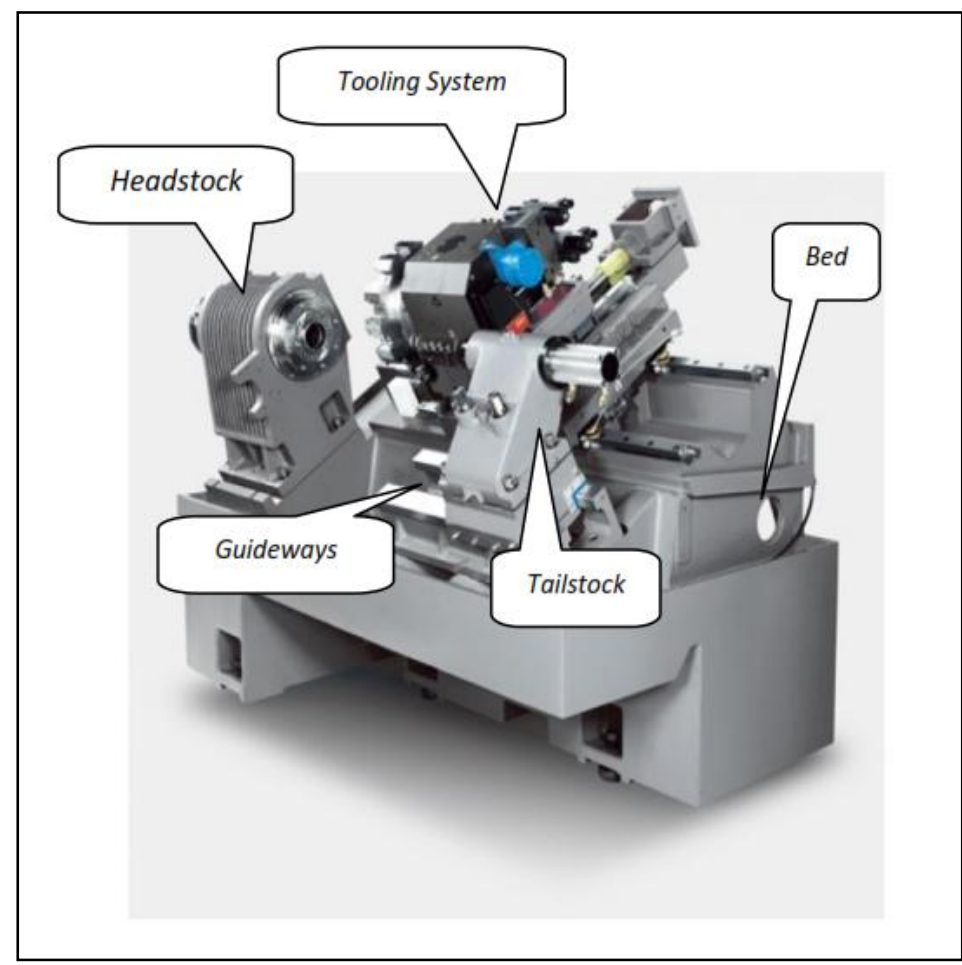

\section{Gambar 2. Komponen utama mesin bubut CNC (sumber: Leadwell product brochure)}

Analisa statis sangat diperlukan pada tahap perancangan desain bed mesin perkakas untuk mengetahui tegangan, regangan dan defleksi struktur, begitu juga dengan analisa dinamis yang digunakan untuk mengetahui frekuensi natural mesin yang berhubungan erat dengan getaran struktur. Kedua hal ini sangat penting untuk mencegah kegagalan kerja mesin ketika dioperasikan [4].

Gaya statis yang bekerja di struktur adalah akibat dari gaya proses/gaya pemotongan dan berat dari komponen mesin serta benda kerja. Gaya statis yang bekerja pada struktur akan mengakibatkan adanya defleksi atau kesalahan geometrik selama proses pemesinan terjadi sehingga hasil proses pemesinan akan berada pada daerah toleransi yang nilainya diperoleh dari kesalahan geometrik akibat pembebanan statis. Adanya kesalahan geometrik ini akan mempengaruhi akurasi hasil proses pemesinan [2].

Analisa dinamis digunakan untuk menentukan karakteristik getaran dan frekuensi pribadi [4]. Akibat dari gaya dinamis ini, akan terjadi getaran atau sering disebut chatter yang mempengaruhi stabilitas dari proses pemesinan.

Proses manufaktur merupakan suatu proses pembuatan benda kerja dari bahan baku sampai barang jadi atau setengah jadi dengan atau tanpa proses tambahan. Pada dasarnya proses manufaktur benda kerja terutama yang berasal dari bahan logam dapat dikelompokkan menjadi: (a) Proses pengecoran (b) Proses pembentukan (c) Proses pemotongan (d) Proses penyambungan (e) Proses perlakuan fisik (f) Proses pengerjaan akhir.

Manufaktur adalah multidisiplin melibatkan desain produk dan kekuatan aspek materi teknik mesin; dasardasar struktur material, pemodelan, dan konsep desain proses pengolahan bahan dan teknik; evaluasi biaya, dasardasar pengolahan manufaktur, kualitas kontrol, dan seluruh aspek manajemen mutu teknik industri. Topik lain, seperti teknik penggunaan alat dan analisis kegagalan. Karena manufaktur melibatkan ilmu pengetahuan yang luas, tentu memerlukan kerja tim yang kompak antara anggota dari berbagai disiplin ilmu teknik. Tim keja ini melibatkan desain, pemilihan bahan, proses seleksi, pemasaran, pembelian, produksi, kualitas, dan fungsi manufaktur lainnya yang diperlukan untuk mengembangkan produk "terbaik" untuk konsumen [5].

Dalam perancangan bed ini Konfigurasi permukaan yang mencakup antara lain kekasaran permukaan dan arah bekas pengerjaan (tekstur), memegang peranan penting dalam perencanaan suatu elemen mesin, yaitu yang berhubungan dengan gesekan, keausan, pelumasan, tahanan kelelahan, kerekatan suaian, dan sebagainya. Konfigurasi permukaan yang diminta perencana harus dinyatakan dalam gambar, menurut cara-cara yang sesuai dengan standar.

Kekasaran permukaan adalah penyimpangan rata-rata aritmetik dari garis rata-rata profil , yang selanjutnya disebut nilai kekasaran (Ra). Nilai kekasaran rata-rata aritmetik telah diklasifikasikan oleh ISO menjadi 12 tingkat kekasaran, dari mulai N1 sampai dengan N12. Untuk penunjukan pada gambar mengenai spesifikasi kekasaran ini dapat dituliskan langsung nilai Ra-nya, atau tingkat keka-sarannya.

Sebagaimana pada tabel 1. nilai kekasaran permukaan suatu elemen ditentukan menurut fungsinya, sedangkan untuk mencapainya bergantung pada kemampuan proses pengerjaan manual atau pemesinan di tempat produksi. 
Tabel 1. Nilai kekasaran permukaan [4]

\begin{tabular}{ccc}
\hline Kekerasan $\boldsymbol{R a}(\boldsymbol{\mu m})$ & Tingkat Kekerasan & Panjang Sampel $(\mathbf{m m})$ \\
\hline 50 & N12 & 8 \\
25 & N11 & \\
12.5 & N10 & \\
6.3 & N9 & 0.8 \\
3.2 & N8 & \\
1.6 & N7 & \\
0.8 & N6 & \\
0.4 & N5 & \\
0.2 & N4 & \\
0.1 & N3 & \\
0.05 & N2 & 0.08 \\
0.025 & N1 & \\
\hline
\end{tabular}

Penjelasan notasi simbol parameter digunakan untuk menunjukkan kekasaran permukaan produk industri, termasuk kekasaran rata-rata aritmatika (Ra), tinggi maksimum (Ry), 10-spot rata kekasaran (Rz), rata-rata jarak cekung-to-cembung (Sm), jarak rata-rata antara puncak lokal (S), dan tingkat panjang beban (tp). Kekasaran permukaan adalah rata-rata aritmatika dari nilai-nilai di tempat yang dipilih secara acak pada permukaan suatu benda [6].

\section{METODOLOGI PENELITIAN}

Proses perancangan dimulai dengan merekonstruksi ulang struktur bed mesin Leadwell T-6 buatan Taiwan yang nantinya akan dijadikan acuan atau akan di-reverse untuk pembuatan mesin bubut CNC yang dibuat oleh BPPT. Gambar 4 adalah hasil rekonstruksi ulang mesin bubut CNC Leadwell T-6 melalui software Solidworks 2013.

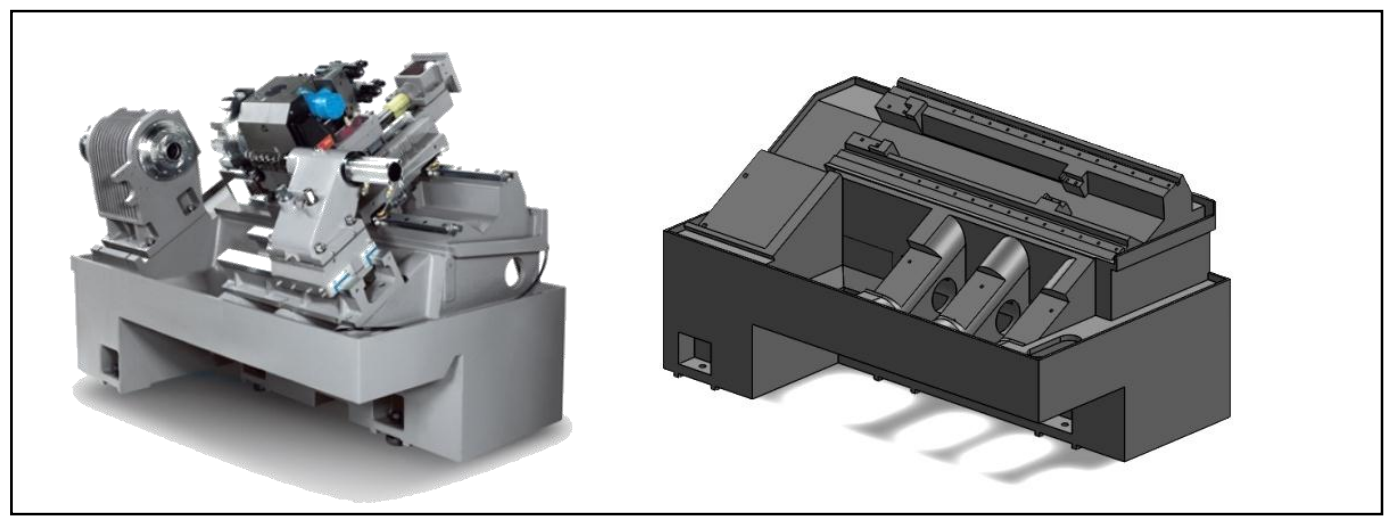

\section{Gambar 3. Rekontruksi Desain Bed Existing}

Berdasarkan data material yang telah ada sebelumnya, diperoleh berat struktur bed menurut Solidworks 2013 adalah 1.546 ton $\mathrm{kg}$. Untuk bentuk ribbing yang digunakan adalah ribbing diagonal seperti ditunjukkan gambar di bawah ini

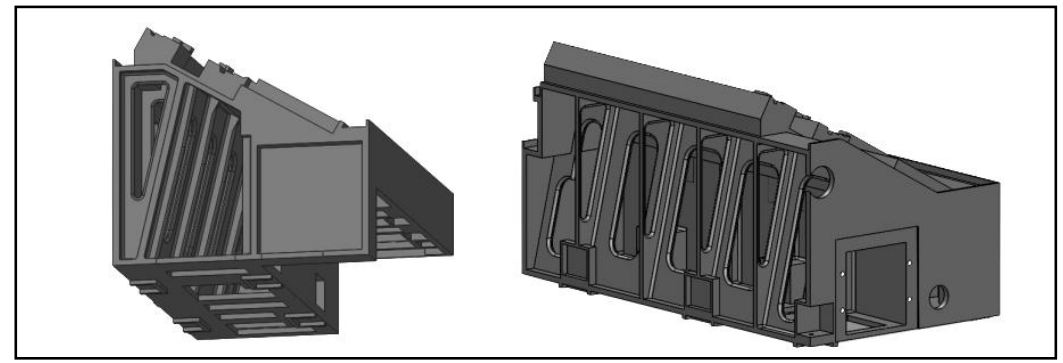

Gambar 4. Pemotongan Desain Bed Existing

Dari desain bed yang ada, penulis mencoba memodifikasi desain bed tersebut dan diperoleh 3 desain utama untuk menjadi pertimbangan desain selanjutnya: 
a) Desain 1 - Vertical ribbing dengan pemotongan bagian belakang bed $\mathrm{I}$

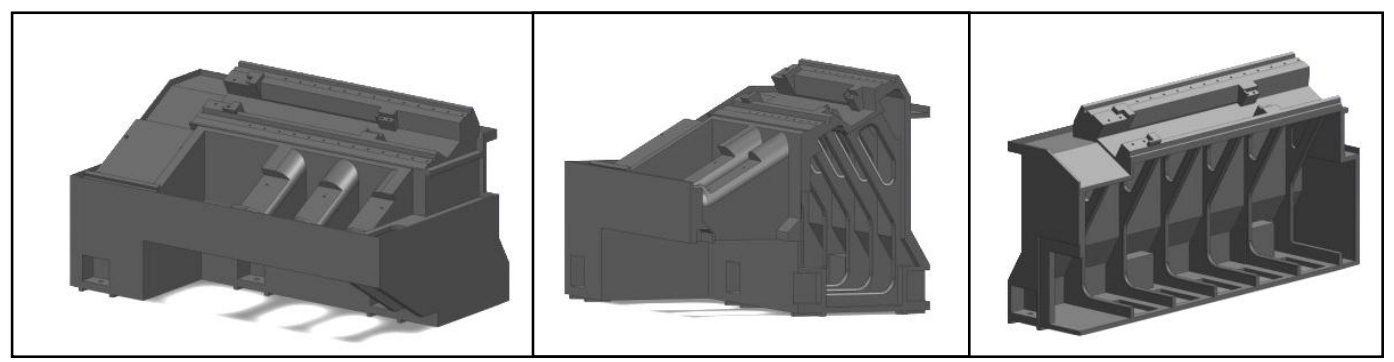

Gambar 5. (a) isometri depan desain I (b) pemotongan desain dari samping; (c) pemotongan desain dari depan

b) Desain 2 - Diagonal Ribbing dengan tambahan rib di bawah tailstock

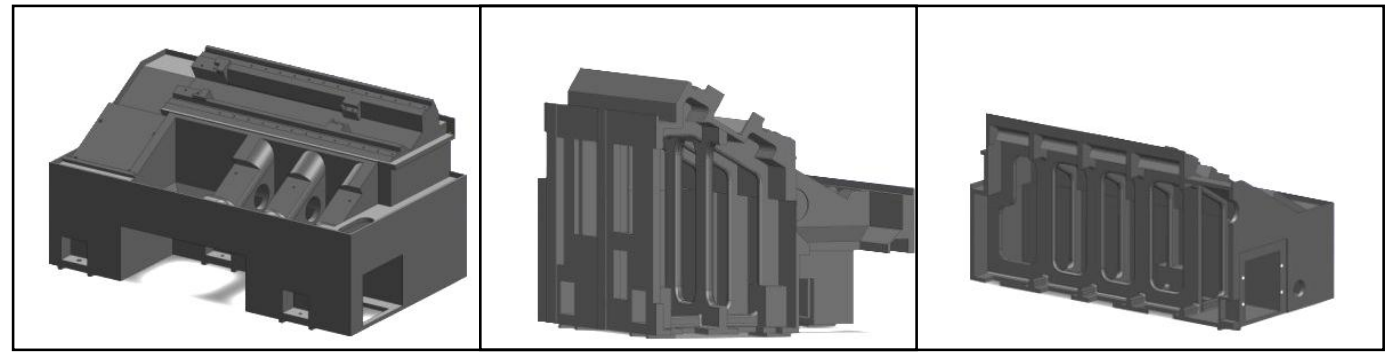

Gambar 6. (a) isometri depan desain II (b) pemotongan desain dari samping (c) Pemotongan Desain Dari Belakang

c) Desain 3 - Vertical ribbing dengan pemotongan bagian belakang bed II

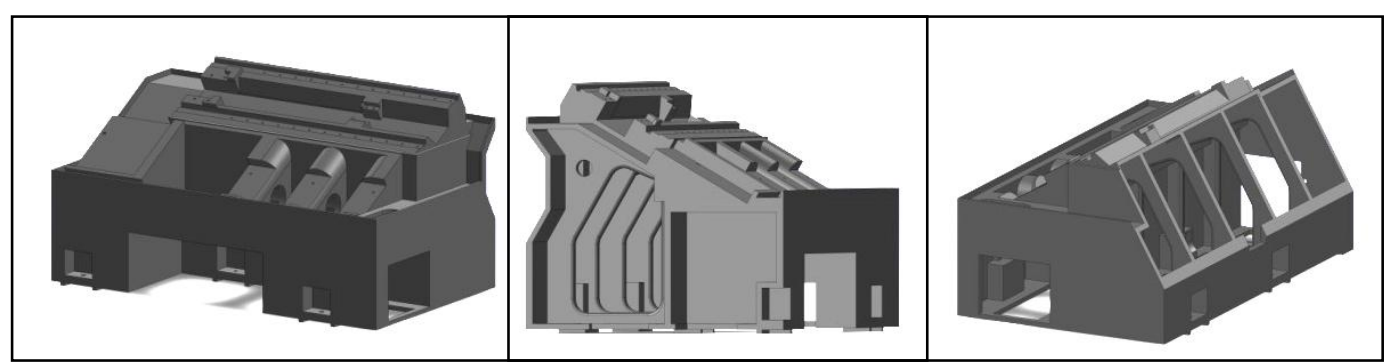

Gambar 7. (a) isometri depan desain III (b) pemotongan desain dari samping (c) Pemotongan Desain Dari Belakang

Setelah diperoleh desain existing dan 3 desain modifikasi, langkah selanjutnya yang dilakukan oleh penulis adalah memberi pembebanan statis pada bed yang nantinya akan dianalisis lebih lanjut. Secara umum, di dalam mesin bubut CNC ada 6 komponen utama, yaitu bed, tooling system/turret, guideways, tailstock, headstock, dan motor penggerak. Untuk komponen mesin seperti pahat, scrap conveyor dapat dimasukkan kategori komponen tambahan. Dalam pembebanan statis ini akan dibuat beberapa asumsi untuk memudahkan proses perhitungan dan analisis, antara lain:

1) Pembebanan akibat berat komponen yang diterima oleh bed adalah dari tailstock, headstock, tooling system/turret, dan guideways.

2) Berat motor listrik diabaikan untuk pembebanan.

3) Gaya berat yang diterima oleh bed terdistribusi merata/tidak pada satu titik pada bagian bed yang menerima pembebanan.

4) Akan dilakukan 2 analisis, saat gaya pemotongan terjadi maksimum dan saat gaya pemotongan sesuai katalog mesin Leadwell sebagai pembanding.

5) Gaya pemotongan radial dapat diabaikan karena nilainya terlalu kecil.

6) Tailstock tidak dipakai saat proses pemotongan sehingga gaya pemotongan dari pahat akan dialirkan benda kerja seluruhnya ke headstock.

Perlu dijelaskan pada asumsi keempat, adanya dua analisis yaitu ketika gaya pemotongan maksimum dan ketika gaya pemotongan sesuai katalog mesin Leadwell diperlukan sebagai tolak ukur ketercapaian kualitas mesin dibanding mesin Leadwell dan sebagai patokan kualitas mesin ketika beban yang terjadi maksimal sehingga 
nantinya akan dicantumkan pada katalog mesin kondisi-kondisi yang harus dihindari saat proses pemesinan dilakukan.

Berdasarkan software Solidworks 2013, diperoleh berat komponen antara lain [2]:

a) Headstock + motor : $375 \mathrm{~kg}$

b) Berat tooling system + Guideways Z Axis : $350 \mathrm{~kg}$

c) Berat Tailstock + Guideways X Axis : $210 \mathrm{~kg}$

d) Berat motor hidrolik + ball screw : $70 \mathrm{~kg}$

Untuk analisis pertama, saat gaya pemotongan maksimum gambar 8.c digunakan gaya pemotongan arah vertikal (FT) sebesar $2263.5 \mathrm{~N}$ dan gaya pemakanan (Ff) sebesar $679 \mathrm{~N}$. untuk analisis kedua gambar 8.b, nilai gaya pemotongan arah vertikal (FT) sebesar $72 \mathrm{~N}$ dan gaya pemakanan (Ff) sebesar $24 \mathrm{~N}$.

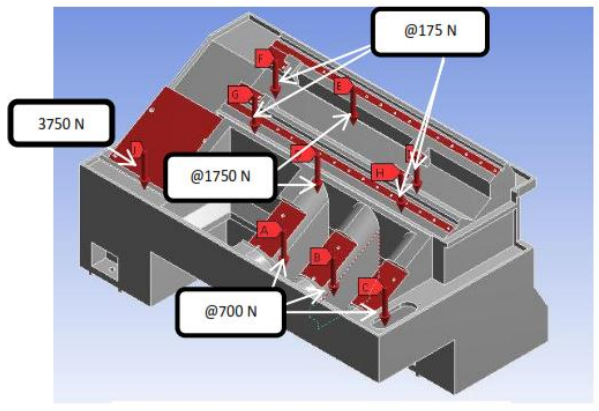

$\mathbf{a}$

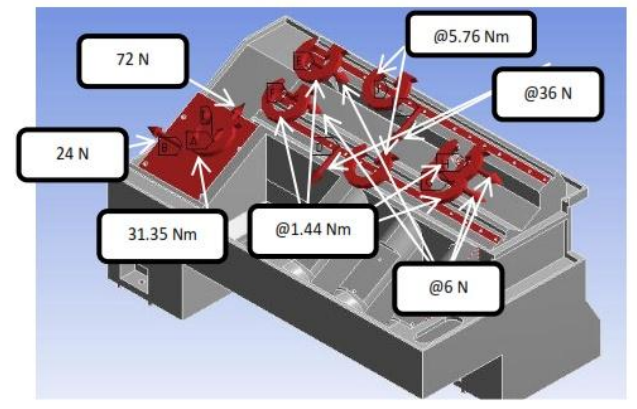

c

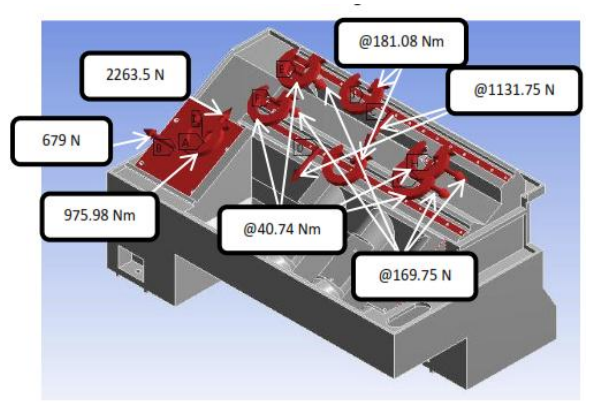

b

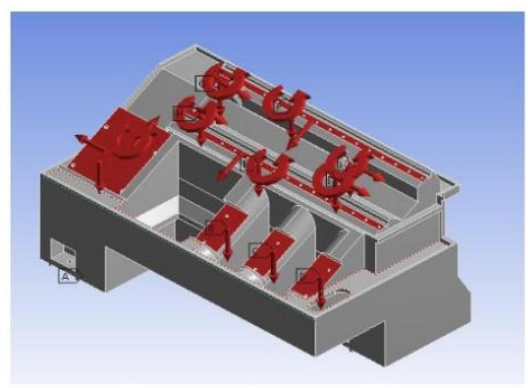

d

Gambar 8. (a) Diagram Benda Bebas akibat berat komponen, (b) Diagram Benda Bebas akibat gaya pemotongan maksimum, (c) Diagram Benda Bebas akibat gaya pemotongan sesuai katalog, (d) Diagram Benda Bebas keseluruhan yang diterima Bed berikut:

Melalui software ANSYS R15.0 daerah pembebanan seperti asumsi ketiga dapat dilihat pada gambar 9

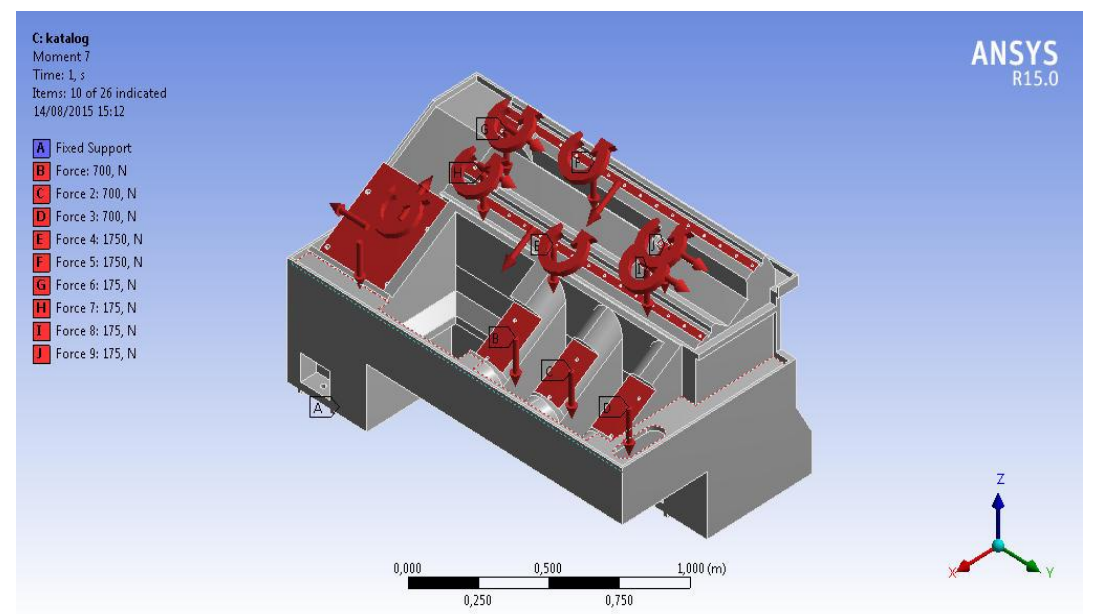

Gambar 9. Pemberian gaya pada software ANSYS R15.0

Setelah dilakukan pemberian beban dengan nilai seperti dicantumkan di atas, berikutnya dilakukan analisis statis untuk melihat defleksi statis dan tegangan Von Mises yang terjadi di struktur baik saat terjadi gaya 
pemotongan maksimal maupun gaya pemotongan sesuai katalog. Selain analisis statis, dilakukan pula analisis dinamis untuk melihat nilai frekuensi pribadi dari struktur dan daerah kritis yang mungkin terjadi saat frekuensi pribadi tersebut terjadi.

\section{HASIL PENELITIAN DAN PEMBAHASAN}

\subsection{Analisa Statis}

a) Desain 1ribbing back-cut versi I

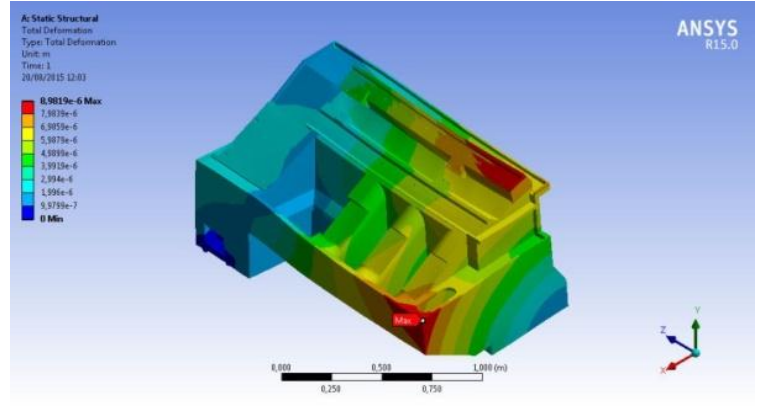

$\mathbf{a}$

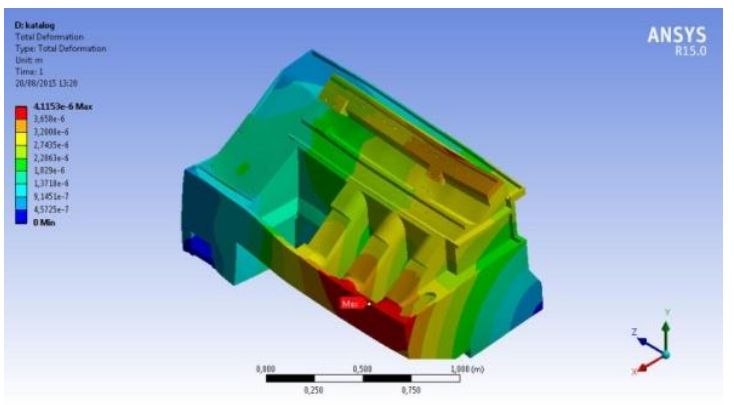

b

Gambar 10. Defleksi statis pada desain I saat gaya potong (a) maksimum (b) katalog

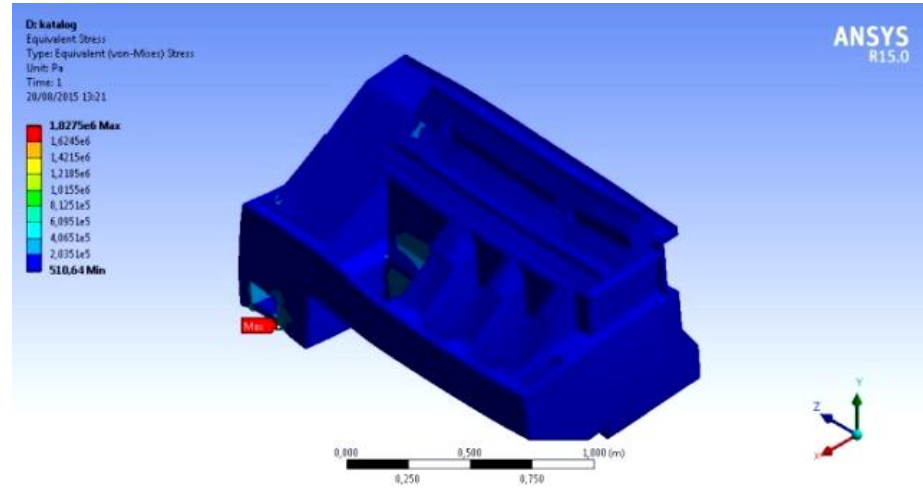

Gambar 11. Persebaran tegangan von Mises pada desain I

b) Desain 2 Ribbing diagonal

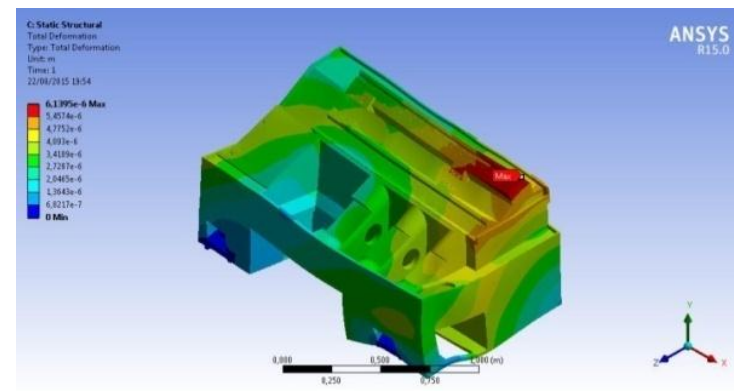

$\mathbf{a}$

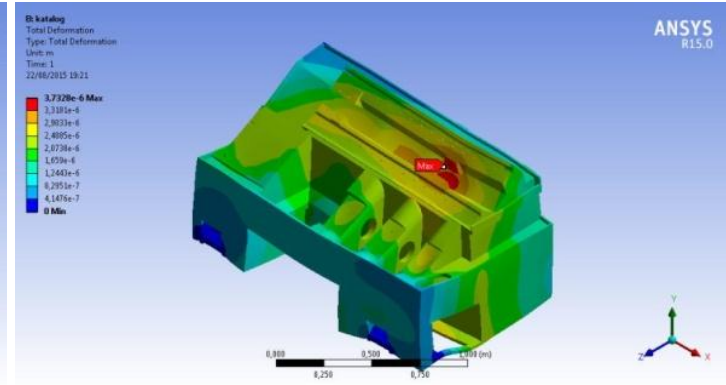

b

Gambar 12. Defleksi statis pada desain II saat gaya potong (a) maksimum (b) katalog 


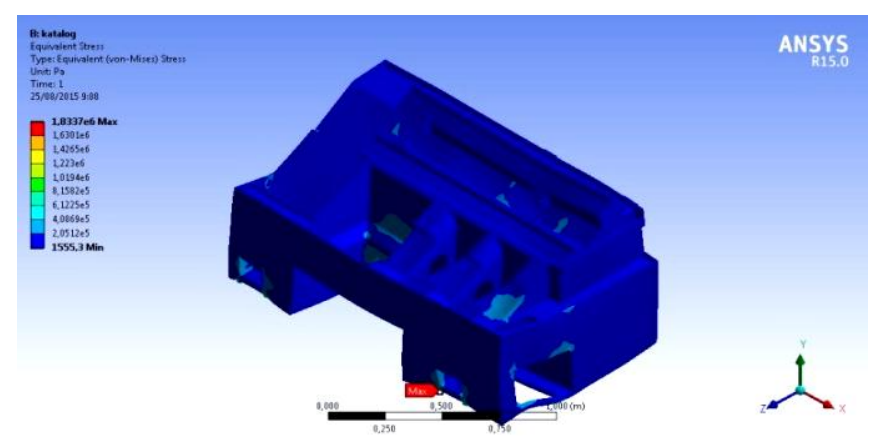

Gambar 13. Persebaran tegangan von Mises pada desain II

c) Desain 3 ribbing back-cut versi II

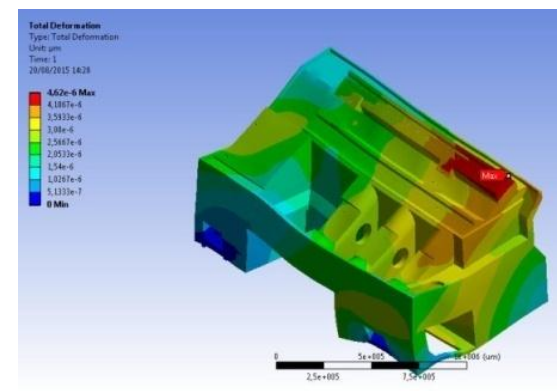

a

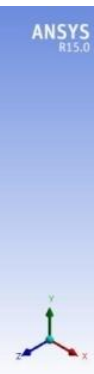

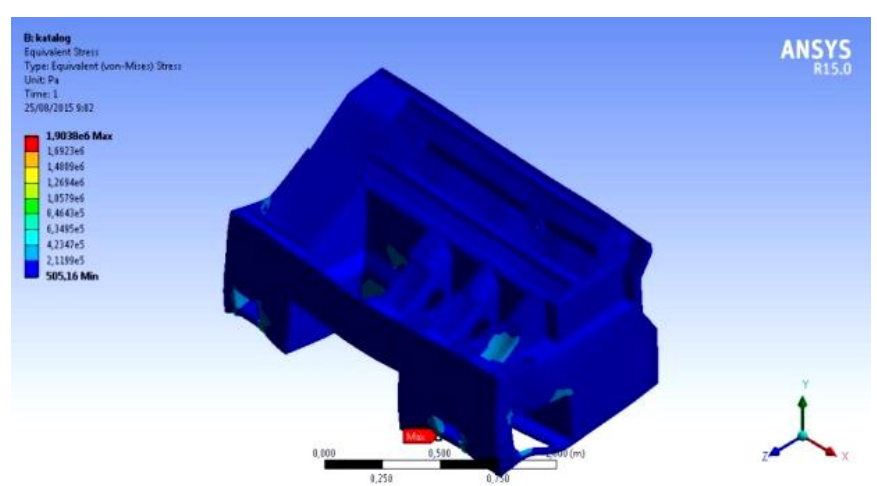

Gambar 15. Persebaran tegangan von Mises pada desain 3

\subsection{Analisi Dinamis}

Tabel 2. Daftar frekuensi pribadi ketiga desain

\begin{tabular}{cccc}
\hline \multirow{2}{*}{ Mode } & \multicolumn{3}{c}{ Frequency[Hz] } \\
\cline { 2 - 4 } & $\begin{array}{c}\text { Vertical ribbing back- } \\
\text { cut versi II }\end{array}$ & $\begin{array}{c}\text { Diagonal } \\
\text { ribbing }\end{array}$ & $\begin{array}{c}\text { Vertical ribbing back-cut } \\
\text { versi II }\end{array}$ \\
\hline 1 & 156.26 & 166.37 & 171.4 \\
2 & 226.16 & 203.82 & 210.68 \\
3 & 281.99 & 243.92 & 251.33 \\
4 & 291.63 & 327.26 & 344.25 \\
5 & 340.92 & 383.17 & 393.04 \\
6 & 393.94 & 409.27 & 421.92 \\
\hline
\end{tabular}
tabel 3 .

Dari hasil analisis statis dan dinamis tersebut, perbandingan untuk masing-masing desain ditunjukkan pada 
Tabel 3. Perbandingan masing-masing desain ribbing

\begin{tabular}{|c|c|c|c|c|c|}
\hline No & Desain & Berat (ton) & $\begin{array}{c}\text { Defleksi } \\
\text { statis }(\mu \mathrm{m})\end{array}$ & $\begin{array}{c}\text { Tegangan von } \\
\text { Mises }(\mathrm{MPa})\end{array}$ & $\begin{array}{c}\text { Frekuensi } \\
\text { Pribadi } 1(\mathrm{~Hz})\end{array}$ \\
\hline 1 & Existing & 1.546 & 5.6609 & 2.2234 & 130.97 \\
\hline 2 & $\begin{array}{l}\text { Vertical Ribbing } \\
\text { back cut Versi I }\end{array}$ & 1.528 & 4.1153 & 1.3275 & 156.26 \\
\hline 3 & Diagonal ribbing & 1.547 & 3.7328 & 1.8337 & 166.37 \\
\hline 4 & $\begin{array}{l}\text { Vertical Ribbing } \\
\text { back cut Versi II }\end{array}$ & 1.542 & 2.752 & 1.9038 & 171.40 \\
\hline
\end{tabular}

Tabel 4. Perbandingan relatif masing-masing desain ribbing

\begin{tabular}{clcccc}
\hline No & \multicolumn{1}{c}{ Desain } & Berat (ton) & $\begin{array}{c}\text { Defleksi } \\
\text { statis }(\boldsymbol{\mu m})\end{array}$ & $\begin{array}{c}\text { Tegangan von } \\
\text { Mises }(\mathbf{M P a})\end{array}$ & $\begin{array}{c}\text { Frekuensi } \\
\text { Pribadi 1 (Hz) }\end{array}$ \\
\hline 1 & Existing & Datum & Datum & Datum & datum \\
2 & $\begin{array}{l}\text { Vertical Ribbing } \\
\text { back cut Versi I }\end{array}$ & + & + & + & + \\
3 & $\begin{array}{l}\text { Diagonal ribbing } \\
\text { Vertical Ribbing }\end{array}$ & - & ++ & + & + \\
4 & back cut Versi II & + & +++ & + & + \\
\hline
\end{tabular}

Mesin bubut CNC leadwell T-6 ini juga memiliki frekuensi pribadi yg cukup rendah, yaitu $130.97 \mathrm{~Hz}$. Berdasarkan katalog, mesin ini beroperasi maksimum pada putaran spindle 4500 RPM atau setara dengan $75 \mathrm{~Hz}$. Nilai selisih antara putaran spindle dengan frekuensi pribadi ini sebenarnya cukup jauh, yaitu $55 \mathrm{~Hz}$, namun tidak dapat mengantisipasi jika terjadi salah pemotongan atau terjadinya proses pemesinan dengan kedalaman potong yang besar hingga menghasilkan chatter sehingga struktur ini rawan gagal jika operator tidak pandai dalam menggunakan mesin ini. Struktur yang baik adalah ketika frekuensi kerja maksimum dari beban yang ada bernilai 1/3 dari frekuensi pribadi strukturnya [7]. Struktur yang baik seharusnya memiliki frekuensi pribadi pertama kali di angka $225 \mathrm{~Hz}$.

Dari 3 modifikasi desain yang ada, perbaikan desain meliputi aspek statis dan dinamik. Dalam hal dinamik, walau belum mencapai angka $225 \mathrm{~Hz}$, ketiga desain sudah menunjukkan kenaikan frekuensi pribadi pertama di angka $155-170 \mathrm{~Hz}$ yang menunjukkan perbaikan desain. Dari aspek dinamik, masih belum dapat diputuskan untuk memilih 1 desain terbaik.

Dari aspek statis, ketiga desain ini lebih kuat dibanding desain CNC leadwell T-6 karena nilai tegangan von Mises-nya lebih kecil, artinya struktur mampu mendistribusikan pembebanan yang dialaminya dengan baik, namun 3 desain tersebut kurang optimal karena safety factor struktur tersebut sangat tinggi serta dilihat dari Yield strength materialnya yang masih jauh di angka $250 \mathrm{MPa}$ sedangkan struktur modifikasi hanya berada di angka 1,4-1,6 MPa.

Dari aspek defleksi statis, desain dengan ribbing back-cut versi II menunjukkan perbedaan cukup signifikan dibanding desain lain dengan defleksi di angka $2.753 \mu \mathrm{m}$ yang memberikan defleksi statis terkecil. Dari aspek ini menunjukkan bahwa desain dapat digunakan untuk desain bed mesin bubut CNC BPPT yang selanjutnya akan dimanufaktur.

\subsection{Desain manufaktur}

Metode desain penambahan ribbing terbukti dapat meningkatkan kekuatan struktur bed dengan jenis material yang sama dan pengurangan jumlah material yang digunakan. Hal ini dapat menjadi acuan meningkatnya kualitas struktur mesin. Optimasi yang dilakukan memberikan hasil pada penurunan biaya produksi bed mesin yang akan dibuat. Perubahan desain modifikasi pada desain ribbing back-cut versi II ditunjukan pada gambar 16-19.

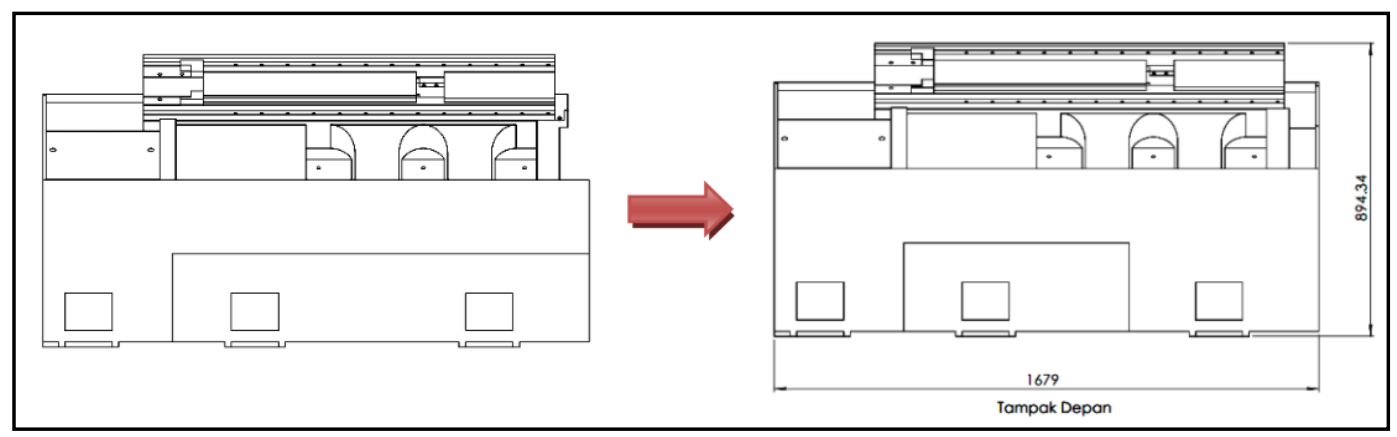

Gambar 16. Penambahan ribbing dibawah tailstock 


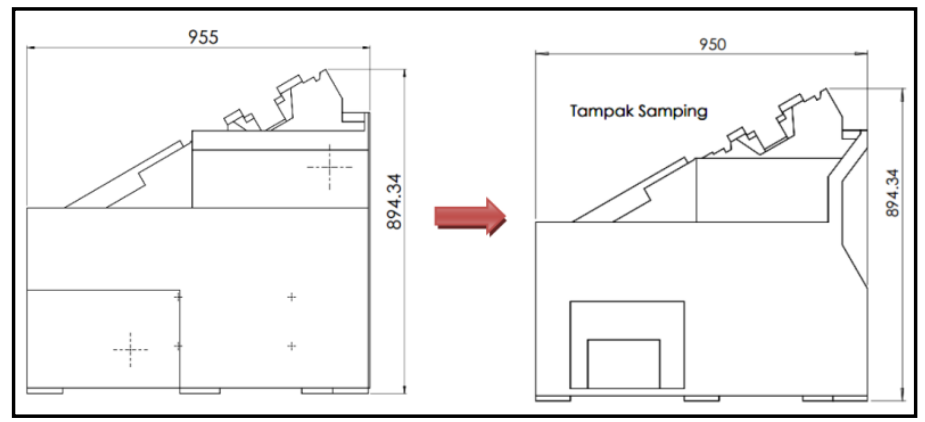

Gambar 17. Pemotongan bagian delakang bed

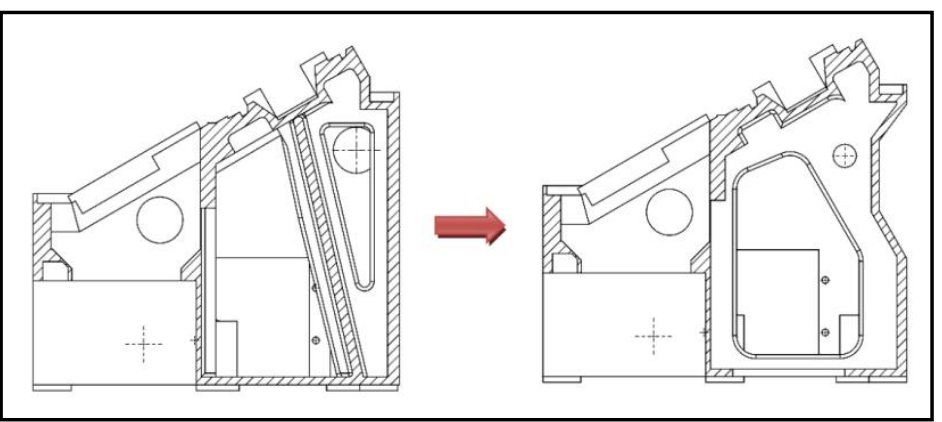

Gambar 18. Perbedaan ribbing bagian dalam bed

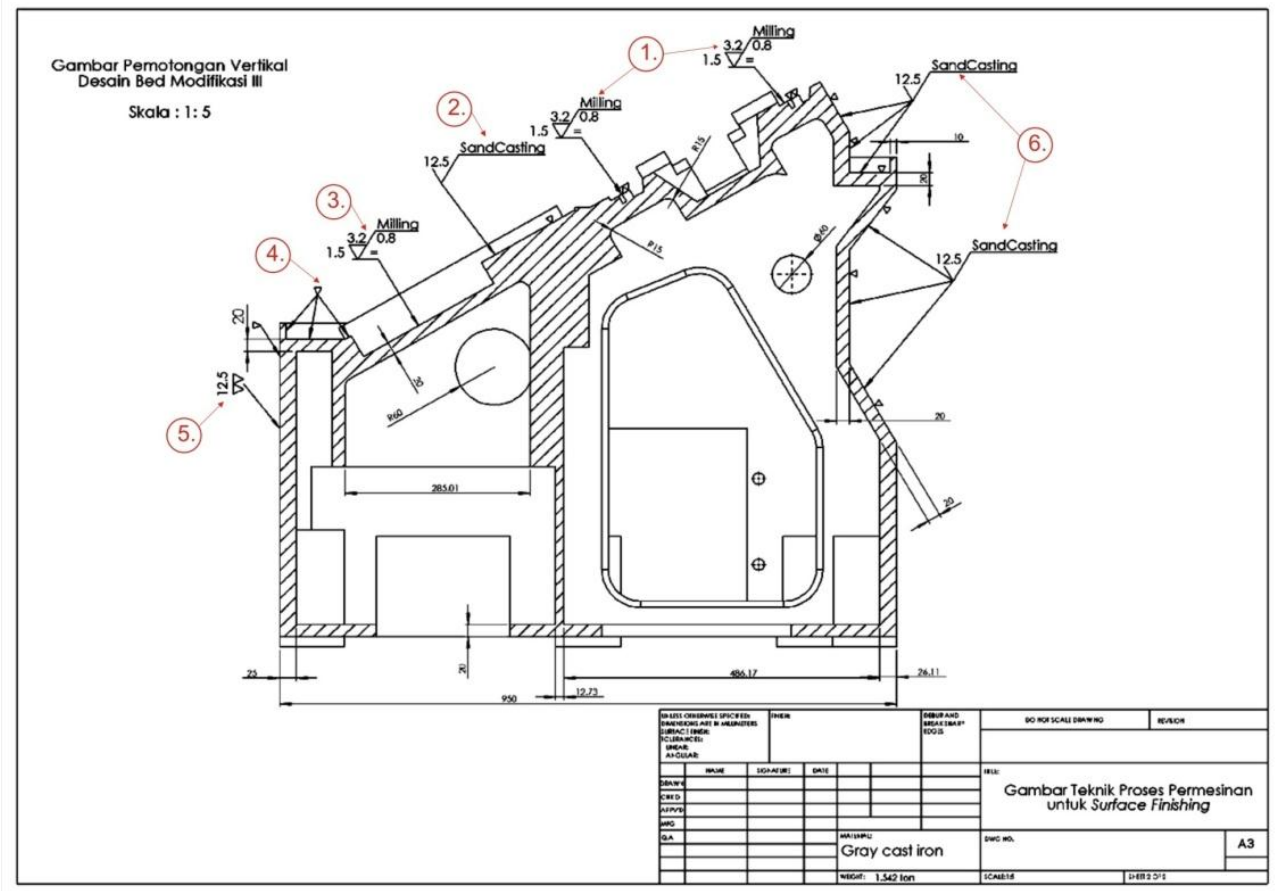

Gambar 19. Proses Surface Finishing desain bed terpilih

Gambar 19 adalah gambar teknik proses pengerjaan permukaan desain terpilih dari tiga desain yang penulis buat. Gambar ini digunakan untuk panduan proses manufaktur bed yang akan dibuat termasuk pemilihan mesin miling plano yang dapat melakukan pengerjaan permukaan sesuai dimensi bed.

Desain yang tepat dari struktur mesin perkakas membutuhkan pengetahuan mendalam tentang bentuk desain mereka dan sifat material, dinamisa proses pemesinan tertentu dan sifat dari komponen yang menyusunnya. Barubaru ini, penelitian telah dilakukan di bidang perbaikan desain struktural dari peralatan mesin dengan meningkatkan kekakuan dan keringanan berat badan yang terutama mendesak untuk bagian-bagian struktural, seperti tempat tidur, kolom, meja kerja, balok dan sebagainya. Susunan rusuk (Ribbing) di struktur mesin perkakas merupakan faktor kunci untuk kekakuan struktural dan konsumsi bahan. Sehingga desain keringanan dari ribbing signifikan untuk kerja mmesin dan menghemat biaya. 
Berikut pejelasan masing-masing prosess permesinan sesuai gambar 19:

a. Proses no 1

Angka 1.5 menunjukkan bahwa dimensi permukaan yang akan di kerjakan harus diberi kelonggaran sebesar 1.5 milimeter sebelum dilakukan penyelesaian akhir (finishing) melalui permesinan. Dalam prakteknya, pencantuman angka kelonggaran ini tidak diharuskan ada karena biasanya sudah diketahui bahwa untuk pemrosesan kembali suatu permukaan sudah tentu harus ada kelebihan dimensi ukuran dari permukaan tersebut. Dalam gambar kerja, biasanya dicantumkan angka kelonggaran, tetapi angka kelonggaran untuk permesinan.

Angka 3,2 menunjukkan bahwa kekasaran rata-rata maksimum yang diijinkan adalah 3,2 mm. Pada Tabel 1 dapat dilihat angka-angka kekasaran Ra dari 12 kelas kekasaran. Ada pula satuan lain yang biasa digunakan untuk menyatakan harga kekasaran rata-rata selain $\mathrm{mm}$ yaitu microinch atau $\mathrm{ru}, 1 \mathrm{ru}=0.025 \mathrm{~mm}$. Pada bagian atas dari tanda segitiga terdapat tulisan yang berbunyi milling, artinya: penyelesaian akhir dari permukaan (finishing) dilakukan dengan menggunakan mesin (milling machine). Kadang-kadang dicantumkan pula keterangan lain dalam penyelesaian permukaan, misalnya proses pengerasan, proses pelapisan, proses pancaran pasir, dan sebagainya.

Angka 0,8 menunjukkan angka panjangnya sampel pengukuran yang harus diambil dalam pemeriksaan kekasaran permukaan dari komponen yang dibuat tersebut. Jadi, angka 0,8 pada contoh di atas artinya adalah panjang sampel untuk pemeriksaan kekasaran sama dengan 0,8 milimeter.

Simbol = artinya: arah bekas pengerjaan sejajar dengan bidang proyeksi dari potongan tempat tanda dipakai.

b. Proses no 2

Angka 12,5 menunjukkan bahwa kekasaran rata-rata maksimum yang diijinkan adalah 12,5 mm. Pada Tabel 2.4 dapat dilihat angka-angka kekasaran $\mathrm{Ra}$ dari 12 kelas kekasaran. Ada pula satuan lain yang biasa digunakan untuk menyatakan harga kekasaran rata-rata selain mm yaitu microinch atau $\mathrm{ru}, 1 \mathrm{ru}=0.025 \mathrm{~mm}$. Pada bagian atas dari tanda segitiga terdapat tulisan yang berbunyi sand casting, artinya: penyelesaian akhir dari permukaan (finishing) dilakukan dengan menggunakan hasil dari sand casting.

c. Proses no 4

Tanda $\nabla$ artinya proses pengerjaannya dengan sandcasting dan forging dengan harga Ra 12,5 - 25,0 dan rata-rata maksimum kekerasan yang diijinkan adalah $12,5 \mathrm{~mm}-25,0 \mathrm{~mm}$.

d. Proses no 5

Tanda $\nabla \nabla$ menjelaskan proses pengrjaannya dengan harga Ra 3,2 - 6,3 dan rata-rata maksimum kekerasan yang di ijinkan adalah $3,2 \mathrm{~mm}-6,3 \mathrm{~mm}$.

Untuk proses permesinan dari bed ke 3 tersebut dengan ukuran bed yang telah ada, menggunakan Portal Type Plano Miller, model FLP 1600,dengan spesifikasi berikut :

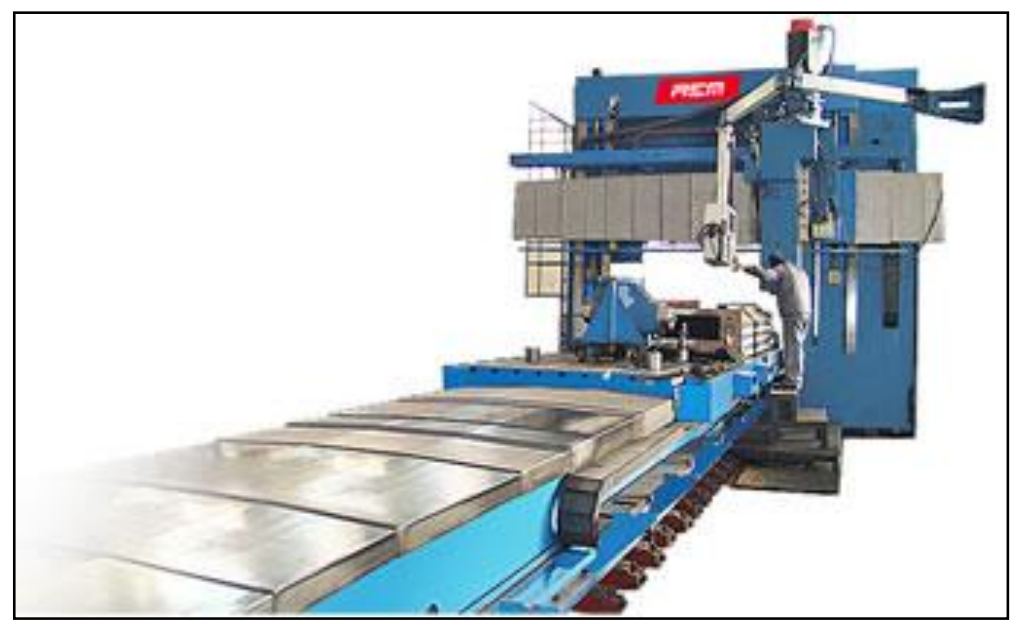

Gambar 20. Portal Type Plano Miller, model FLP 1600

Gambar 20 menunjukan Jenis Portal Type plano miller Model FLP dirancang untuk mesin mekanik berbagai bagian yang terbuat dari besi cor atau baja, baja ditempa atau struktur dilas. Jenis mesin dapat melakukan pengerjaan seadanya, finishing dan operasi penggilingan super-akhir serta pengeboran dan memotong benang. Mesin-mesin dapat dikendalikan dalam mode otomatis melalui peralatan CNC atau manual (mode MDI) dari panel kontrol pusat. 
Tabel 4. Spesifikasi Mesin Milling Plano

\begin{tabular}{ccc}
\hline Spesification & M.U. & FLP 1600 \\
\hline Table size & $\mathrm{mm}$ & $4000 \times 1620$ \\
Max.load on table & in & $157 \times 64$ \\
Kg/m & 4000 \\
Table longitudional travel $(x)$ & $\mathrm{mm}$ & 4600 \\
Head longtudional travel $(y)$ & in & 181 \\
& $\mathrm{~mm}$ & 2500 \\
Ram vertikal travel $(z)$ & in & 98 \\
& $\mathrm{~mm}$ & 1000 \\
Spindle taper & in & 39 \\
Spindle speed range & $\mathrm{rpm}$ & $10-3000$ \\
Main motor power & $\mathrm{kW}$ & 30 \\
& $\mathrm{hp}$ & 40 \\
Distance between columns & $\mathrm{mm}$ & 2000 \\
Max. Distance between table and & in & 79 \\
spindle front surface & $\mathrm{mm}$ & 2150 \\
& in & 85 \\
\hline
\end{tabular}

\section{KESIMPULAN}

1) Desain existing perlu dirancang ulang.

2) Modifikasi desain vertical ribbing dengan pemotongan bagian belakang bed II memiliki nilai defleksi statis yang paling baik diantara modifikasi desain yang lain.

3) Modifikasi desain vertical ribbing dengan pemotongan bagian belakang bed II merupakan desain terkuat dari desain yang ada dengan nilai tegangan von mises terkecil.

4) Tiga modifikasi desain menunjukkan perbaikan nilai frekuensi pribadi dari struktur bed.

5) Proses manufaktur pengerjaan permukaan disarankan menggunakan mesin Portal Type Plano Miller, model FLP 1600

\section{DAFTAR PUSTAKA}

[1] Abuthakeer , S. Syath . 2011. "Structural Redesigning Of A Cnc Lathe Bed To Improve Its Static And Dynamic Characteristics". International Journal of Engineering-Tome IX. 3, 389-384.

[2] Youssef, Helmi A., and El-Hofy, Hassan. (2008). Machining Technology: Machine Tools and Operations, USA: CRC Press.

[3] Mazid ,A. M. (2007). "Evaluation of dynamic quality of lathe machines to categorise them for better productivity and accuracy reducing defects".5th Australasian Congress on Applied Mechanics, ACAM 2007. Australia: Monash University

[4] Subrahmanyam ,B.V. 2013. "Static and Dynamic Analysis of Machine Tool Structures". InternatIonal Journal of research In MechanIcal engIneerIng \& technology 4. 14-18.

[5] Creese, G. Robert. (1999). Introduction to Manufacturing Processes and Material. USA: Marcel Dekker, Inc.

[6] JIS B 0601.(1994). Technical Data: Surface Roughness. Halaman 1257-1258

[7] Weck, Manfred. (1984). Handbook of Machine Tools Volume 2: Construction and Mathematical Analysis, Inggris: John Wiley \& Sons. 